\section{REFERENCES}

1. Denny FW, Murphy TF, Clyde WA, Collier AM, Henderson FW 1983 Croup: an 11-year study in a pediatric practice. Pediatr 71:871-876

2. Hall CE, Brandt CD, Frothingham TE, Spigland I, Cooney MK, Fox JP 1971 The virus watch program: a continuing surveillance of viral infections in Metropolitan New York families. Am J Epidemiol 94:367-385

3. Welliver R, Wong DT, Choi TS, Ogra PL 1982 Natural history of parainfluenza virus infection in childhood. J Pediatr 101:180-187

4. Welliver RC, Wong DT, Middleton E, Sun M, McCarthy N, Ogra PL 1982 Role of parainfluenza virus-specific $\mathrm{IgE}$ in pathogenesis of croup and wheezing subsequent to infection. J Pediatr 101:889-896

5. Gollapudi SVS, Kind LS 1977 Inhibition of IgE production in mice by nonspecific suppressor T cells. Int Arch Allergy Appl Immunol 53:395-401

6. Zuraw BL, Nonaka M, O'Hair C, Katz DH 1981 Human IgE antibody synthesis in vitro: stimulation of $\mathrm{IgE}$ responses by pokeweed mitogen and selective inhibition of such responses by human suppressive factor of allergy (SFA). J Immunol 127:1169-1177

7. Buckley RH, Sampson HA, Fisher PM, Becker WG, Shirley LR 1982 Abnormalities in the regulation of human IgE synthesis. Ann Allergy 49:67-72

8. Thomas Y, Hucht R, Granjon D 1981 Histamine-iduced suppressor cells of lymphocyte mitogenic response. Cell Immunol 59:268-275

9. Wong DT, Welliver RC, Riddlesberger KR, Sun MS, Ogra PL 1982 Rapid diagnosis of parainfluenza virus infection in children. $\mathrm{J}$ Clin Microbiol 16:164-167

10. Welliver RC, Kaul A, Ogra PL 1979 Cell-mediated immune response to respiratory syncytial virus infection: relationship to the development of reactive airway disease. $\mathrm{J}$ Pediatr 94:370-375

11. Rocklin RE, Beard J, Gupta S, Good RA, Melmon KL 1980 Characterization of the human blood lymphocytes that produce a histamine-induced suppressor factor (HSF). Cell Immunol 51:226-237

12. Damle NK, Gupta S 1981 Autologous mixed lymphocyte reaction in man. II. Histamine-induced suppression of the autologous mixed lymphocyte reaction by $\mathrm{T}$-cell subsets defined with monoclonal antibodies $\mathrm{J}$ Clin Immunol $1: 241-249$

13. Welliver RC, Wong DT, Sun M, Middleton E, Vaughan RS, Ogra PL. 198
The development of respiratory syncytial virus-specific $\operatorname{IgE}$ and the release of histamine in nasopharyngeal secretions after infection. $N$ Engl $J$ Med 305:841-846

14. Welliver RC, Kaul TN, Sun M, Ogra PL 1984 Defective regulation of immune responses in respiratory syncytial virus infection. J Immunol 133:1925-1930

15. Martinez JD, Santos J, Stechschulte DJ, Abdou NI 1979 Nonspecific suppressor cell function in atopic subjects. J Allergy Clin Immunol 64:485-490

16. Beer DJ, Osband ME, McCaffrey RP, Soter NA, Rocklin RE 1982 Abnormal histamine-induced suppressor-cell function in atopic subjects. N Engl J Med 306:454-458

17. Konig P 1978 The relationship between croup and asthma. Ann Allergy 41:227-231

18. Zach M, Erben A, Olinsky A 1981 Croup, recurrent croup, allergy, and airways hyper-reactivity. Arch Dis Child 56:336-341

19. Zach MS, Schnall RP, Landau LI 1980 Upper and lower airway hyperreactivity in recurrent croup. Am Rev Respir Dis 121:979-983

20. Gurwitz D, Corey M, Levison H 1980 Pulmonary function and bronchial reactivity in children after croup. Am Rev Respir Dis 122:95-99

21. Thueson DO, Speck LS, Lett-Brown MA, Grant JA 1979 Histamine-releasing activity (HRA). I. Production by mitogen- or antigen-stimulated human mononuclear cells. J Immunol 123:626-632

22. Bamzai AK, Kretschmer RR 1978 Enhancement of antigen-induced leukocyte histamine release by a mononuclear cell-derived factor. J Allergy Clin Immunol 62:137-142

23. Atkins PC, Valenzano M, Zweiman B 1982 Plasma concentrations of histamine measured by radioenzymatic assay: effects of histaminase incubations. $J$ Allergy Clin Immunol 69:39-45

24. Adams GK, Lichtenstein L 1979 In vitro studies of antigen-induced bronchospasm: effect of antihistamine and SRS-A antagonist on response of sensitized guinea pig and human airways to antigen. J Immunol 122:555-562

25. Canonica GW, Mingari MC, Melioli G, Colombatti M, Moretta L 1979 Imbalances of $T$ cell subpopulations in patients with atopic diseases and effect of specific immunotherapy. J Immunol 123:2669-2672

26. Rocklin RE, Sheffer AL, Greineder DK, Melmon KL 1980 Generation of antigen-specific suppressor cells during allergy desensitization. N Engl J Med 302:1213-1219

\title{
Morphologic and Metabolic Development of Human Fetal Epiphyseal Chondrocytes in Primary Culture
}

\author{
ANTONIO CARRASCOSA, LAURA AUDİ, AND ANGEL BALLABRIGA \\ Children's Hospital of the Seguridad Social, Autonomous University of Barcelona, Paseo del Valle Hebron s/n, \\ 08035 Barcelona, Spain
}

\begin{abstract}
Primary chondrocyte culture was carried out after enzymatic digestion of femoral and tibial epiphyseal cartilage of human fetuses, collected with informed parental consent within $12 \mathrm{~h}$ postmortem. Chondrocytes were cultured in HAM F-12 medium with penicillin and $15 \%$ serum. Three types of serum were used: human placental cord serum (HPS), fetal calf serum, and human male adult serum. Chondrocytes cultured with HPS grew as monolayers, formed abundant colony groups with a highly metachromatic pericellular matrix, and floating round cells were observed in the culture medium. By the 10th day of culture
\end{abstract}

Received May 17, 1984; accepted February 27, 1985

Reprint requests Antonio Carrascosa, Clinica Infantil Valle Hebron, Paseo del Valle Hebron s/n, 08035 Barcelona, Spain.

Supported by Grant 301/81 from "Fondo de Investigaciones Sanitarias de la Seguridad Social," España. the great majority of proteoglycans present in the culture medium were found as aggregates. Chondrocytes cultured with fetal calf serum or human male adult serum grew as monolayers, were polygonal in shape, and the pericellular matrix was far less developed than in HPS cultures. By the confluent phase of growth, only approximately a third of the proteoglycans present in the culture medium were found as aggregates. Chondrocytes cultured with HPS proliferated significantly more rapidly than those cultured with fetal calf serum or human male adult serum. The results suggest that certain, as yet unidentified, factors are present in sufficient amount in HPS to allow chondrocytes in culture to retain phenotypic morphological and biochemical characteristics. HPS also facilitates growth of human fetal epiphyseal chondrocytes in culture. Primary human 
fetal epiphyseal chondrocyte culture could be a suitable experimental tool for the in vitro study of biochemical characteristics of cartilage and factors involved in fetal cartilage metabolism. (Pediatr Res 19: 720-727, 1985)

\section{Abbreviations}

HPS, human placental cord serum

FCS, fetal calf serum

HAS, human adult male serum

$\mathrm{CPC}$, cetyl piridinium chloride

Human cartilage is a widespread tissue in the body with welldefined functions according to its location. The role of epiphyseal cartilage in promoting skeletal growth has been recognized since the endochondral calcification process was first described (1). Skeletal growth is particularly important during human fetal life. However, little is known of the biochemical characteristics of human fetal epiphyseal cartilage and the factors involved in cartilage metabolism.

Recently, chondrocyte cultures have been used for the in vitro study of biochemical characteristics of cartilage (2-10) and factors involved in cartilage metabolism (11-19).

The aim of this work was to study the morphological and metabolic development of human fetal epiphyseal chondrocytes in primary culture.

\section{METHODS}

Chondrocyte culture. Primary chondrocyte culture was carried out with subtle modification of the method of Corvol et al. (20).
Tibial and femoral epiphyseal cartilage from human fetuses (1232 wk old), products of miscarriage or premature delivery, were collected with informed parental consent within $12 \mathrm{~h}$ postmortem (Table 1). Fetuses with skeletal malformations were excluded. Under sterile conditions the epiphyseal cartilage was cleaned of surrounding tissue and the articular surface and calcifying zones were removed by dissection. The remaining cartilage was cut in thin slices and finely chopped with a surgical blade. This tissue mixture was digested at $37^{\circ} \mathrm{C}$ for $30 \mathrm{~min}$ with trypsin (Difco Laboratories, Detroit, $\mathrm{MI}$ ) $0.2 \%$ in HAM F-12 medium (Grand Island Biological Co., Grand Island, NY) followed by two collagenase (Worthington Biochemical Corp, Freehold, NJ) digestions, $0.2 \%$, in HAM F-12 medium, the first for $60 \mathrm{~min}$ and the second for $30 \mathrm{~min}$. A pure chondrocyte suspension was obtained and chondrocytes were plated at different cell densities $\left(0.5 \times 10^{5}, 1 \times 10^{5}\right.$, and $\left.2 \times 10^{5}\right)$ in $25 \mathrm{~cm}^{2}$ plastic tissue culture flasks (Corning Glass Works, Corning, NY) with 4 ml of HAM F-12 medium supplemented with penicillin (25 IU/ $\mathrm{ml}$ ) and $15 \%$ serum (Table 1). Three types of serum were used: HPS, HAS, and FCS and chondrocytes were cultured in four different serum conditions (Table 1). The flasks were maintained at $37^{\circ} \mathrm{C}$ in an atmosphere of $5 \% \mathrm{CO}_{2}$ in air with humidity and the cultures were fed by changing the medium every 2 days.

HPS was collected from placental cord of normal deliveries at term, passed through $0.22 \mu \mathrm{m}$ Millex-GS filters (Millipore, Molsheim, France) and kept frozen at $-20^{\circ} \mathrm{C}$ in sterile conditions until used. Fourteen different batches were made, one for each culture (Table 1). HAS was obtained from five male adult volunteers, filtered through $0.22 \mu \mathrm{m}$ Millex-GS filters and frozen at $-20^{\circ} \mathrm{C}$ in sterile conditions until used; one pooled batch was made. Four different batches of FCS (Grand Island Biological

Table 1. Human fetuses used for chondrocyte cultures

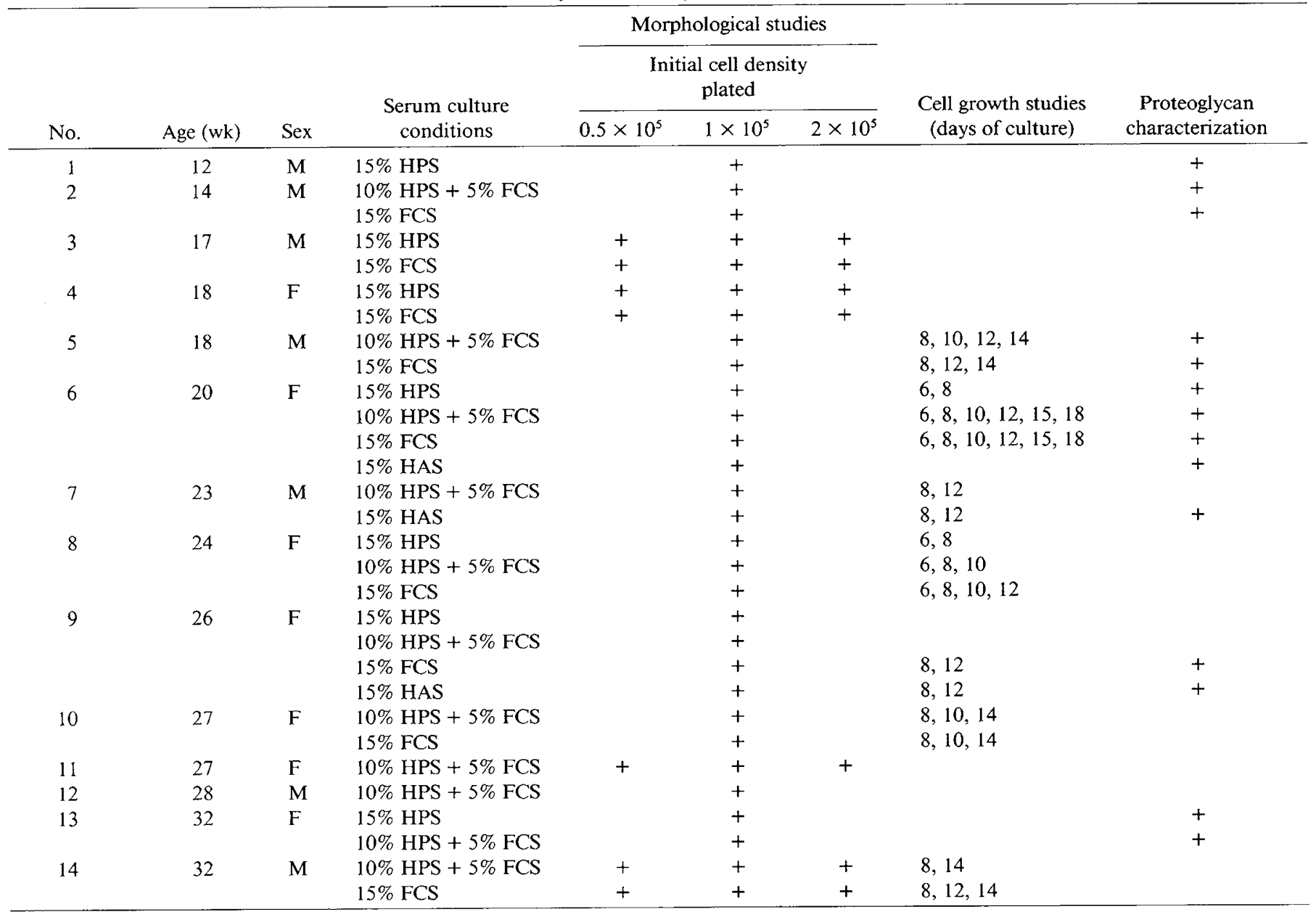



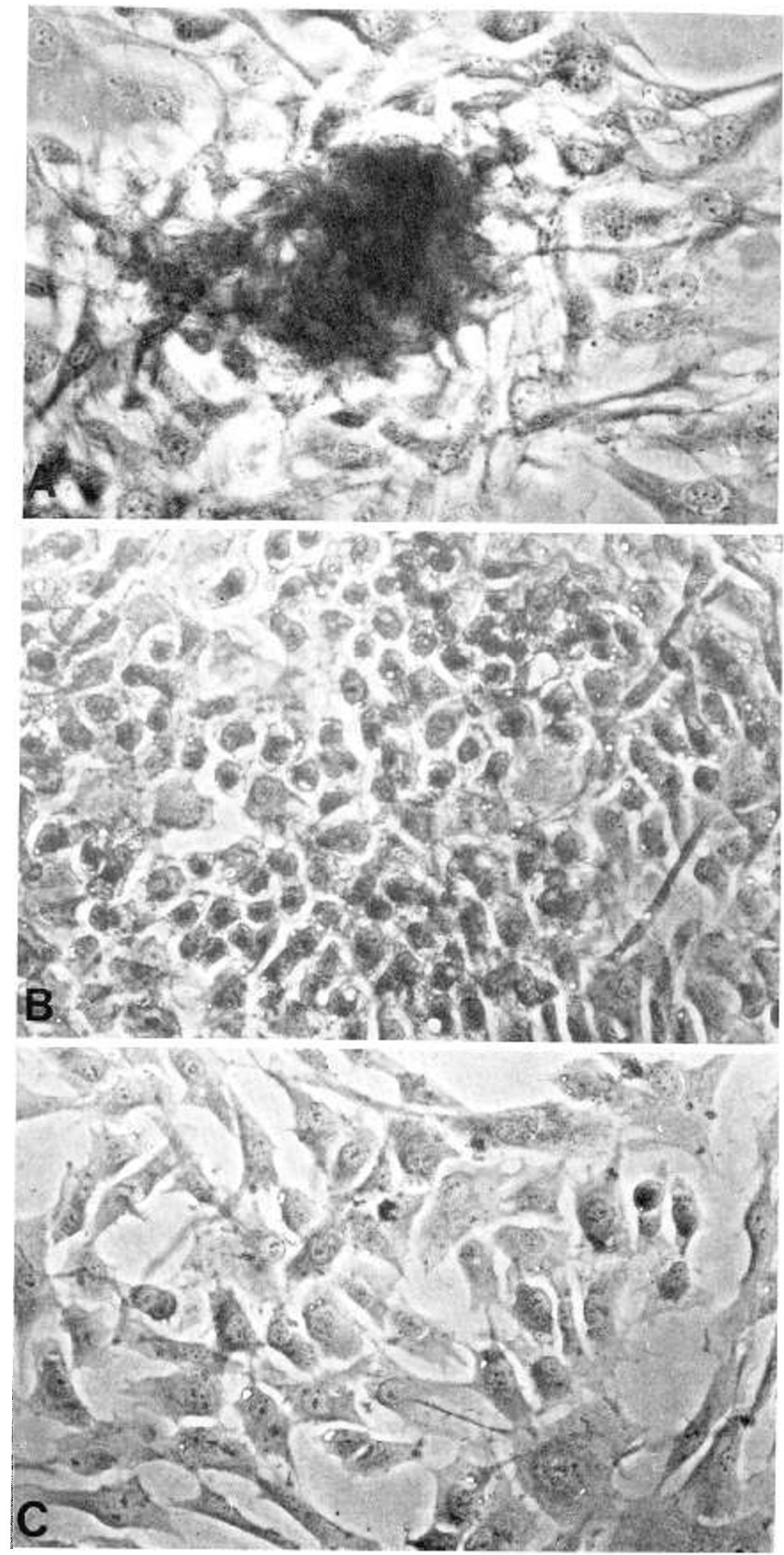

Fig. 1. The phase-contrast picture of chondrocytes in primary culture for a 20 -wk-old fetus. $A$, chondrocytes cultured with $15 \%$ HPS, 10 th day of culture. Note the intense metachromatic pericellular matrix of one colony group. $B$, chondrocytes cultured with $10 \%$ HPS plus $5 \%$ FCS, 12 th day of culture. Chondrocytes are polygonal in shape. Note grouping in colonies with pericellular metachromatic matrix. $C$, chondrocytes cultured with $15 \%$ FCS by the confluent phase of growth. Chondrocytes were polygonal and the metachromatic pericellular matrix was far less developed than in $15 \%$ HPS cultures. 
$\mathrm{Co}$, Grand Island, NY) were used: batch 1 in cultures 1,2 , and 6 ; batch 2 in cultures $3,4,5$, and 11 , batch 3 in cultures 7, 9, 10 , and 12 , batch 4 in cultures 8,13 , and 14 .

Morphological studies. The morphology of chondrocytes plated at different cell densities and cultured in different serum conditions (Table 1) were observed by phase contrast microscopy. On the 10th day of culture for chondrocytes cultured with $15 \%$ HPS and at the beginning of confluency for chondrocytes cultured in the other serum conditions, the culture medium was aspirated and the cells were stained directly with $0.25 \%$ aqueous toluidine blue in sodium acetate-acetic buffer, $\mathrm{pH}$ 4.5. The morphology and metachromacy of chondrocytes were then observed by phase contrast microscopy.

Cell growth studies. One hundred thousand chondrocytes released by enzymatic digestion from epiphyseal cartilage were plated in a $25 \mathrm{~cm}^{2}$ culture flask with $4 \mathrm{ml}$ of HAM F-12 medium, penicillin $(25 \mathrm{IU} / \mathrm{ml})$, and $15 \%$ serum. Chondrocytes were cultured in four different serum conditions: $15 \%$ HPS, $10 \%$ HPS plus $5 \%$ FCS, $15 \%$ FCS, and $15 \%$ HAS (Table 1). The cultures were fed by changing the medium every 2 days. As mentioned above the HPS batches used in these cultures differed from one culture to another. A common batch of HAS and four batches of FCS were used.

On different days of culture (Table 1) three flasks were trypsinized $\left(0.25 \%\right.$ trypsin in phosphate-buffered saline, $\left.37^{\circ} \mathrm{C}, 10 \mathrm{~min}\right)$. From each separate flask cells were collected, rinsed in phosphate-buffered saline, resuspended in order to obtain a single cell suspension, counted by means of a hemocytometer, centrifuged, and the DNA measured following Burton's method (21).

Characterization of proteoglycans synthesized by epiphyseal cartilage. Fetal epiphyseal cartilage was collected under sterile conditions, cut in fine slices, and chopped by hand with a surgical blade. An average of $0.5 \mathrm{~g}$ of tissue was incubated in $4 \mathrm{ml}$ Dubelcco's (Grand Island Biological Co.) with $6 \mu \mathrm{Ci}$ of $\mathrm{Na}_{2}{ }^{35} \mathrm{SO}_{4}$ (SA $232.44 \mathrm{mCi} / \mathrm{mmol}$, New England Nuclear, Boston, MA) for $20 \mathrm{~h}$. The medium was recovered and labeled proteoglycans were precipitated and eluted in a Sepharose 2B (Pharmacia Fine Chemicals AB, Upssala, Sweden) column according to Wiebkin's method (22). CPC 5\% (Sigma Chemical Co, St. Louis, MO) was added to the medium to a final concentration of $1 \%$ in the presence of $50 \mathrm{mM}$ EDTA (E Merck AG, Darmstadt, FRG), 0.5 M 6-aminohexanoic acid (E Merck AG), and $25 \mathrm{mM}$ benzamidine $\mathrm{HCl}$ (Sigma Chemical Co.) as proteinase inhibitors, after which the mixture was gently shaken overnight at room temper- ature. The CPC precipitates thus formed were centrifuged at $3640 \times g$ at $15^{\circ} \mathrm{C}$, washed once with $5 \mathrm{ml}$ of $0.1 \mathrm{M} \mathrm{Na}_{2} \mathrm{SO}_{4}$, then dissolved in $2 \mathrm{ml}$ of $1.25 \mathrm{M} \mathrm{MgCl}_{2}$; the material was reprecipitated with $8 \mathrm{ml}$ of ice-cold ethanol and left at $4^{\circ} \mathrm{C}$ for $16 \mathrm{~h}$. The ethanol precipitates were centrifuged at $3640 \times g$ at $4^{\circ}$ $\mathrm{C}$ for $10 \mathrm{~min}$, redissolved in $0.5 \mathrm{M}$ sodium acetate $(\mathrm{pH} \mathrm{6.8)}$, and samples containing approximately $3000 \mathrm{cpm}$ of labeled proteoglycans were applied to a column $(30 \times 0.8 \mathrm{~cm})$ of Sepharose $2 \mathrm{~B}$. The column was eluted with $0.5 \mathrm{M}$ sodium acetate ( $\mathrm{pH}$ 6.8) at a flow rate of $10 \mathrm{ml} / \mathrm{h}$. Fractions of $0.350 \mathrm{ml}$ were collected and radioactivity counted in $10 \mathrm{ml}$ of Unisolve (Koch Light Laboratories, Colnbrook Berks, England) in a $\beta$-counter (Isocap 300 -Searle) for $10 \mathrm{~min}$.

Characterization of proteoglycans synthesized by chondrocytes in primary culture. On the 10th day of culture for chondrocytes cultured with $15 \%$ HPS and at the beginning of the confluent phase of growth for chondrocytes cultured in the other different serum conditions, the culture medium was aspirated and replaced by $4 \mathrm{ml}$ of Dubelcco's serum-free medium with penicillin $(25 \mathrm{IU} / \mathrm{ml})$. Twenty-four hours later the culture medium was again replaced by $4 \mathrm{ml}$ of Dubelcco's antibiotic and serum-free medium with $6 \mu \mathrm{Ci}$ of $\mathrm{Na}_{2}{ }^{35} \mathrm{SO}_{4}$. After $20 \mathrm{~h}$ of incubation the culture medium and the cells were collected separately. The medium was aspirated and the cells were washed twice with $0.9 \%$ $\mathrm{NaCl}$ and collected in $2 \mathrm{ml}$ of distilled water. Labeled proteoglycans present in the culture medium and the cells were precipitated by CPC and ethanol as described above. Samples containing $3000-5000 \mathrm{cpm}$ of labeled proteoglycans were applied and eluted in a Sepharose 2 B column as described above.

Statistics. Mean values and SDs were calculated. The differences between groups were analyzed by Student's $t$ test.

\section{RESULTS}

Chondrocytes of human fetal epiphyseal cartilage are able to grow in primary culture, but culture characteristics differ with the type of serum used.

Morphological studies. Chondrocytes cultured with 15\% HPS had become attached to the bottom of the flask by the second day after plating. They developed as monolayers, were polygonal in shape, and formed separate colony groups in which cells were surrounded by an intense metachromatic pericellular matrix (Fig. 1). Between the 6 th and 8 th days of culture single round cells and clusters of cells appeared floating in the culture medium.

Table 2. Means $\pm S D$ of total cell number and DNA on different days of culture; chondrocytes were plated at initial cell density of 1 $\times 10^{5}$ cells per flask and cultured under varied serum conditions $(+)$

\begin{tabular}{|c|c|c|c|c|}
\hline $\begin{array}{l}\text { Day of } \\
\text { culture }\end{array}$ & $\begin{array}{l}\text { Serum culture } \\
\text { conditions }\end{array}$ & $\begin{array}{c}\text { No. of flasks } \\
\text { studied }\end{array}$ & Cell no. $\left(\times 10^{3}\right)$ & DNA $(\mu \mathrm{g})$ \\
\hline \multirow[t]{3}{*}{6} & $15 \%$ HPS & 6 & $371.6 \pm 39.7^{* *}$ & $3.50 \pm 0.60^{* * *}$ \\
\hline & $10 \% \mathrm{HPS}+5 \% \mathrm{FCS}$ & 6 & $368.3 \pm 44.4^{* *}$ & $3.28 \pm 0.29^{* * * *}$ \\
\hline & $15 \%$ FCS & 6 & $225.5 \pm 53.4$ & $2.30 \pm 0.34$ \\
\hline \multirow[t]{4}{*}{8} & $15 \% \mathrm{HPS}$ & 6 & $766.1 \pm 117.8^{* * *}$ & $7.03 \pm 1.14^{* * * *}$ \\
\hline & $10 \% \mathrm{HPS}+5 \% \mathrm{FCS}$ & 18 & $758.3 \pm 162.5^{* * * *}$ & $7.07 \pm 1.08^{* * * *}$ \\
\hline & $15 \% \mathrm{FCS}$ & 18 & $434.3 \pm 105.6$ & $3.82 \pm 0.83$ \\
\hline & $15 \% \mathrm{HAS}$ & 6 & $423.3 \pm 37.7^{\mathrm{NS}_{\dagger}}$ & $3.91 \pm 0.31^{\mathrm{NS}}$ \\
\hline \multirow[t]{2}{*}{10} & $10 \%$ HPS $+5 \%$ FCS & 12 & $1529.7 \pm 240.8^{* * * *}$ & $12.11 \pm 1.51^{* * * *}$ \\
\hline & $15 \% \mathrm{FCS}$ & 9 & $674.2 \pm 157.6$ & $6.11 \pm 1.60$ \\
\hline \multirow[t]{3}{*}{12} & $10 \%$ HPS $+5 \%$ FCS & 9 & $2513.3 \pm 275.3^{* * * *}$ & $16.34 \pm 1.02^{* * * *}$ \\
\hline & $15 \% \mathrm{FCS}$ & 15 & $1113.0 \pm 398.0$ & $8.96 \pm 2.24$ \\
\hline & $15 \%$ HAS & 6 & $1094.5 \pm 177.4^{\mathrm{NS}}$ & $8.51 \pm 1.05^{\mathrm{NS}}$ \\
\hline \multirow[t]{2}{*}{14} & $10 \%$ HPS $+5 \%$ FCS & 9 & $2602.2 \pm 614.4^{*}$ & $17.56 \pm 1.98^{* * * *}$ \\
\hline & $15 \% \mathrm{FCS}$ & 9 & $2022.2 \pm 281.7$ & $14.01 \pm 1.17$ \\
\hline
\end{tabular}

\footnotetext{
${ }^{*} p<0.02 ;{ }^{* *} p<0.01 ;{ }^{* * *} p<0.005 ;{ }^{* * * *} p<0.001$ versus $15 \%$ FCS cultures.
}

$\dagger$ Not significant versus $15 \%$ FCS cultures. 
The number of floating cells increased with time and colonies never became confluent even when the primary culture was maintained for 30 days or more. When floating chondrocytes were replated with $15 \%$ HPS in secondary culture they developed characteristics similar to those observed in primary culture.

Chondrocytes cultured with $15 \%$ FCS were adhering to the flask by the second day, grew as monolayers, and were polygonal in shape. The pericellular matrix was far less developed than in $15 \%$ HPS cultures (Fig. 1). When culture was prolonged beyond confluency the chondrocytes acquired a fibroblast-like shape. No cells or clusters of cells were observed floating in the medium during culture. When floating cells from primary HPS cultures were replated with $15 \%$ FCS, they developed in the same way as FCS primary cultures.

Chondrocytes cultured with $15 \%$ HAS developed similarly to chondrocytes cultured with $15 \%$ FCS.

Chondrocytes cultured with $10 \%$ HPS plus $5 \%$ FCS were attached to the flask by the second day, grew as monolayers, were polygonal in shape, and formed metachromatic colony groups (Fig. 1). If the culture was extended beyond confluency, fibroblast-like cells appeared among the colonies. At confluency, few cells were observed floating in the culture medium.

These morphological serum-dependent characteristics of human fetal epiphyseal chondrocytes in culture were observed in all three initial cell densities plated $\left(0.5 \times 10^{5}, 1 \times 10^{5}\right.$, and $2 \times$ $10^{5}$ cells per flask) and at any gestational age studied (12-32 wk).

Cell growth studies. Table 2 shows the mean $( \pm \mathrm{SD})$ number of cells and DNA present on different days of culture in $25 \mathrm{~cm}^{2}$ flasks when chondrocytes were plated at initial cell density of 1 $\times 10^{5}$ cells per flask, and cultured under different serum conditions and with different serum batches. Chondrocytes cultured with $15 \%$ HPS or $10 \%$ HPS plus $5 \%$ FCS proliferate significantly $(p<0.01)$ more rapidly than those cultured with $15 \%$ FCS or $15 \%$ HAS. No significant differences were observed between the proliferation rates of chondrocytes cultured with $15 \% \mathrm{HPS}$ and those cultured with $10 \%$ HPS plus $5 \%$ FCS. Neither were there significant differences between the proliferation rate of chondrocytes cultured with $15 \%$ FCS and those cultured with $15 \%$ HAS.

Figure 2 shows the cumulative growth curve of 20 wk fetal epiphyseal chondrocytes in primary culture during the first 18 days of culture. Cells were plated at initial cell density of $1 \times 10^{5}$ cells per flask and cultured in parallel with $10 \%$ HPS plus $5 \%$ FCS or $15 \%$ FCS. Chondrocytes cultured with $10 \%$ HPS plus $5 \%$ FCS proliferate significantly $(p<0.02)$ more rapidly than those cultured with $15 \%$ FCS.

Characterization of proteoglycans synthesized by chondrocytes in cartilage incubations and in primary culture. Human fetal epiphyseal chondrocytes in primary culture synthesized proteo- glycans. After precipitation by $\mathrm{CPC}$ and ethanol, approximately $80 \%$ of the total labeled proteoglycans were present in the culture medium and the remaining $20 \%$ in the cellular-pericellular pool. Toluidine blue staining of the cellular-pericellular pool is shown in Figure 1.

Figure 3 shows the elution profile in a Sepharose $2 \mathrm{~B}$ column of labeled proteoglycans precipitated from the incubation medium of epiphyseal cartilage and from the culture medium of 20 -wk fetal chondrocytes cultured under different serum condi-

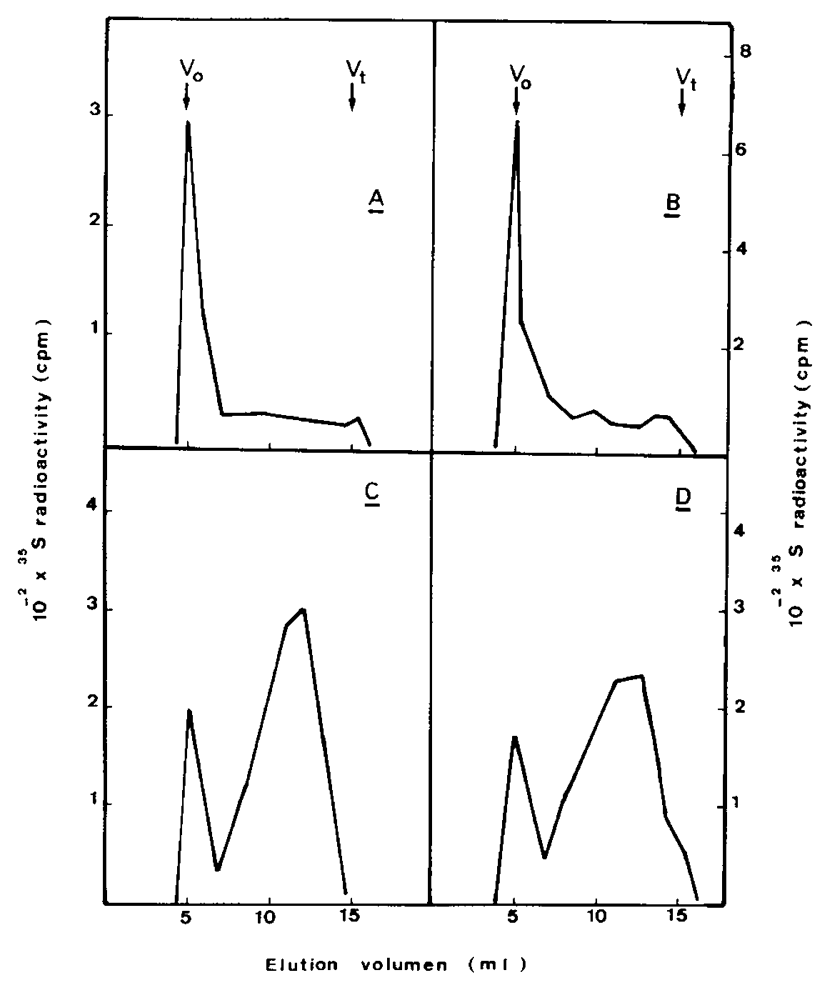

Fig. 3. Sepharose 2B elution profile of labeled proteoglycans from the incubation medium of epiphyseal cartilage and from the culture medium of epiphyseal chondrocytes in primary culture, for a 20 -wk-old fetus. $V_{o}$ is the void volume and $V_{t}$ is the total volume of the column. $A$, labeled proteoglycans from the incubation medium of epiphyseal cartilage. $B$, labeled proteoglycans from the culture medium of chondrocytes cultured with $15 \%$ HPS. $C$, labeled proteoglycans from the culture medium of chondrocytes cultured with $15 \%$ FCS. $D$, labeled proteoglycans from the culture medium of chondrocytes cultured with 15\% HAS.
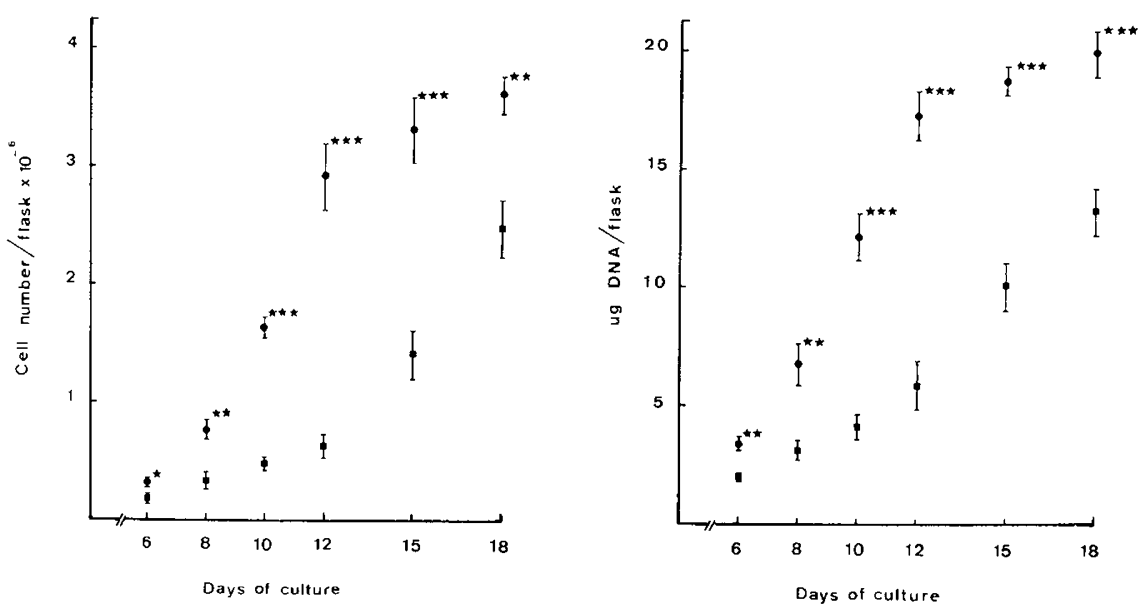

Fig. 2. The cumulative growth curve of fetal epiphyseal chondrocytes in primary culture during the first 18 days of culture, for a 20-wk-old fetus. Chondrocyes were plated at initial cell density of $1 \times 10^{5}$ cells per flask and cultured in parallel with $10 \%$ HPS plus $5 \%$ FCS $(\bullet)$ or $15 \%$ FCS ( $\square$ ). Points and bars are mean \pm SD of three different flasks. ${ }^{*} p<0.02 ;{ }^{* *} p<0.005 ;{ }^{* * *} p<0.001$ versus $15 \%$ FCS culture. 
tions. Labeled proteoglycans from 15\% HPS culture showed the same elution profile as labeled proteoglycans from cartilage incubations, with the great majority eluting as aggregates in the void volume. However, only approximately a third of labeled proteoglycans from $15 \%$ FCS or $15 \%$ HAS cultures eluted as aggregates in the void volume and the remainder eluted in monomer form.

Figure 4 shows the elution profile of labeled proteoglycans precipitated from the cellular-pericellular pool of chondrocytes cultured under different serum conditions, for the same 20 -wkold fetus. Approximately a third of labeled proteoglycans from $15 \%$ HPS culture eluted as aggregates in the Vo and the remainder eluted in monomer form. However, labeled proteoglycans from $15 \%$ FCS culture eluted mainly in monomer form.

Table 3 shows the percentage of labeled proteoglycans eluting in the aggregate and monomer forms after chromatography in a Sepharose 2B column. Results from cartilage incubations and chondrocytes cultured under different serum conditions are quoted according to fetal age and are similar to those described above for a 20 -wk-old fetus.

Recovery of radioactivity from the columns was higher than $70 \%$.

\section{DISCUSSION}

Chondrocytes in culture need growth factors to develop, and FCS is widely used as a source of growth factors. As FCS is a heterologous serum for human fetal chondrocytes, HPS and HAS also were used in our cultures. Certain morphological and biochemical characteristics of human fetal epiphyseal chondrocytes cultured with these different types of serum were characterized.

Chondrocytes in culture grew as monolayers in all three sera,

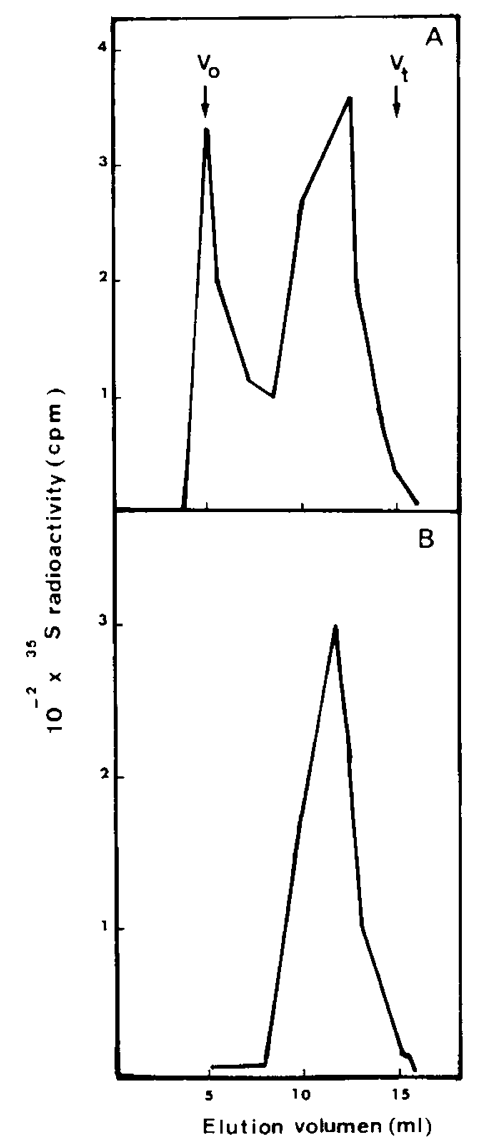

Fig. 4. Sepharose 2B elution profile of labeled proteoglycans from the cellular-pericellular pool, for a 20 -wk-old-fetus. $\mathrm{V}_{\mathrm{o}}$ is the void volume and $\mathrm{V}_{\mathrm{t}}$ is the total volume of the column. $A$, labeled proteoglycans from $15 \%$ HPS culture. $B$, labeled proteoglycans from $15 \%$ FCS culture. but in the presence of HPS, chondrocytes formed colony groups with an intense metachromatic pericellular matrix, and a considerable number of cells and clusters of cells were observed floating in the medium. These floating cells were living cells as shown by their capacity to develop with similar morphological characteristics in secondary culture as in primary culture. Corvol et al. (20) reported the ability to form colonies in primary culture as characteristic for chondrocytes from the proliferative zone of epiphyseal growth plate of immature rabbits. Yasumoto et al. (23) also reported that chick embryo sternal chondrocytes are able to develop in culture as floating cells retaining phenotypic characteristics. In our cultures, chondrocytes form colony groups and floating cells in the presence of HPS in the culture medium. These morphological characteristics were observed in all three initial cell densities plated and at any gestational age studied. This suggests the presence of unidentified factors in sufficient quantity in HPS (but not in FCS or HAS) to facilitate development of these morphological characteristics by human fetal epiphyseal chondrocytes in culture.

Human placental cord serum also contains factors (not apparently present in FCS or HAS) which enhance growth of human fetal epiphyseal chondrocytes in culture. Chondrocytes cultured with $15 \%$ HPS formed colony groups with a well-developed metachromatic pericellular matrix and it was often difficult to attain total cell release by trypsinization. Furthermore, in these cultures, from the 8th day onward, an increasing number of floating cells were lost when the medium was changed for culture feeding. For these reasons, only the cumulative growth curve was studied during the first 8 days of culture. Neither of these two problems was encountered when chondrocytes were cultured with $10 \%$ HPS plus $5 \%$ FCS, $15 \%$ FCS or $15 \%$ HAS, and it was therefore possible to study the cumulative growth curve during the first 18 days of culture.

Proteoglycans together with collagen are the major components of cartilage matrix. Proteoglycans in cartilage are present as large aggregates where many monomers are bound to a single large molecule of hyaluronic acid, and this union is stabilized by link proteins of small molecular weight (24). Human fetal chondrocytes in primary culture synthesized proteoglycans which are mainly found extracellularly in the culture medium. Sepharose 2B gel chromatography of labeled proteoglycans synthesized by chondrocytes in primary culture differed depending on the serum in which the chondrocytes were cultured. Labeled proteoglycans from the culture medium of chondrocytes cultured with $15 \%$ HPS were present principally as aggregates as was the case with the labeled proteoglycans from the incubation medium of epiphyseal cartilage. This indicates that human epiphyseal chondrocytes in primary culture retain this phenotypic characteristic even after $48 \mathrm{~h}$ of serum deprivation. However, only approximately a third of labeled proteoglycans from the culture medium of chondrocytes cultured with FCS or HAS were present as aggregates.

Labeled proteoglycans from the cellular-pericellular pool of chondrocytes cultured with FCS or HAS were found mainly as monomers. Labeled proteoglycans from the same pool of chondrocytes cultured with $15 \%$ HPS, while appearing as monomers, also were present (about 30\%) as aggregates. Kimura et al. (5) and Bjornsson and Heinegard (7) showed that in chondrocyte cultures, proteoglycan monomers, and hyaluronic acid were exported separately from the cell and combined extracellularly to form proteoglycan aggregates. In our cultures, chondrocytes cultured with $15 \%$ HPS formed a well-developed metachromatic pericellular matrix. We can assume that labeled proteoglycans came from two different sources: from inside the cells, where proteoglycans were present as monomers, and from the pericellular matrix, where proteoglycans were present as aggregates. However, when chondrocytes were cultured with HAS or FCS the pericellular matrix was far less developed and it can be assumed that labeled proteoglycans were mainly of intracellular origin. 
Table 3. Percentage of labeled proteoglycans present in aggregate and monomer forms for cartilage incubations and chondrocytes cultured under different serum conditions

\begin{tabular}{|c|c|c|c|c|c|}
\hline \multirow[b]{2}{*}{ No. culture } & \multirow[b]{2}{*}{ Fetal age (wk) } & \multicolumn{2}{|c|}{ Culture medium } & \multicolumn{2}{|c|}{ Cellular-pericellular pool } \\
\hline & & Aggregates & Monomers & Aggregates & Monomers \\
\hline \multicolumn{6}{|c|}{ Cartilage incubations } \\
\hline & 14 & 86.50 & 13.50 & & \\
\hline & 20 & 88.70 & 11.30 & & \\
\hline & 24 & 89.50 & 10.50 & & \\
\hline & 28 & 84.76 & 15.24 & & \\
\hline \multicolumn{6}{|c|}{$\begin{array}{l}\text { Chondrocytes cul- } \\
\text { tured with } 15 \% \\
\text { HPS }\end{array}$} \\
\hline 1 & 12 & 80.80 & 19.20 & 30.40 & 69.60 \\
\hline 6 & 20 & 82.50 & 17.50 & 33.20 & 66.80 \\
\hline 13 & 32 & 83.70 & 16.30 & 35.10 & 64.90 \\
\hline \multicolumn{6}{|c|}{$\begin{array}{l}\text { Chondrocytes cul- } \\
\text { tured with } 10 \% \\
\text { HPS + 5\% FCS }\end{array}$} \\
\hline 2 & 14 & 71.14 & 28.80 & 16.36 & 83.63 \\
\hline 5 & 18 & 75.10 & 24.90 & 15.20 & 84.80 \\
\hline 6 & 20 & 71.57 & 28.42 & 18.50 & 81.50 \\
\hline 13 & 32 & 69.63 & 30.36 & 16.87 & 83.12 \\
\hline \multicolumn{6}{|c|}{$\begin{array}{l}\text { Chondrocytes cul- } \\
\text { tured with } 15 \% \\
\text { FCS }\end{array}$} \\
\hline 2 & 14 & 22.80 & 77.20 & 8.40 & 91.60 \\
\hline 5 & 18 & 22.60 & 77.40 & 8.00 & 92.00 \\
\hline 6 & 20 & 23.20 & 76.80 & 10.50 & 89.50 \\
\hline 9 & 26 & 26.24 & 73.75 & 9.60 & 90.40 \\
\hline \multicolumn{6}{|c|}{$\begin{array}{l}\text { Chondrocytes cul- } \\
\text { tured with } 15 \% \\
\text { HAS }\end{array}$} \\
\hline 6 & 20 & 21.30 & 78.70 & 10.30 & 89.70 \\
\hline 7 & 23 & 25.50 & 74.50 & 8.50 & 91.50 \\
\hline 9 & 26 & 17.45 & 82.50 & 9.10 & 90.90 \\
\hline
\end{tabular}

In conclusion, human fetal epiphyseal chondrocytes can be grown in primary culture and will retain morphological and biochemical phenotypic characteristics. However, to develop these characteristics, certain as yet unidentified factors must be present in the culture medium. These factors are found in sufficient amounts in HPS but not in HAS or FCS. Human placental cord serum, even at term, also provides a suitable pericellular environment for optimal growth of fetal chondrocytes.

Acknowledgments. The authors are grateful to Dr. M. T. Corvol for encouragement and advice as well as to Miss $\mathrm{C}$. O'Hara for useful manuscript corrections. The excellent technical assistance of Mrs. P. Andaluz is gratefully acknowledged.

\section{REFERENCES}

1. Sissons HA 1971 The growth of bone. In: Bourne GH (ed) The Biochemistry and Physiology of Bone. Academic Press, New York, pp 145-180

2. Schindler FH, Ose MA, Solursh M 1976 The synthesis of cartilage collagen by rabbit and human chondrocytes in primary cell culture. In Vitro 12:44-47

3. Müller PK, Lemmen D, Gay S, Gauss V, Kühn J 1977 Immunochemical and biochemical study of collagen synthesis by chondrocytes in culture. Exp Cell Res 108:47-55

4. Madsen K, Lohmander S, Moskalewski S, Hinek A 1978 Proteoglycans synthesized by fetal guinea pig chondrocytes in culture. Connect Tissue Res $5: 205-210$

5. Kimura JH, Hardingham TE, Hascall VD, Solursh M 1979 Biosynthesis of proteoglycans and their assembly into aggregates in cultures of chondrocytes from the swarm rat chondrosarcoma. J Biol Chem 254:2600-2609

6. Desau W, Vertel BM, von der Mark H, von der Mark K 1981 Extracellular matrix formation by chondrocytes in monolayer culture. J Cell Biol 90:7883

7. Björnsson S, Heinegard D 1981 Assembly of proteoglycan aggregates in cultures of chondrocytes from bovine tracheal cartilage. Biochem $\mathbf{J}$ 199:17-29

8. Harmand MF, Cuphil R, Blanquet P 1982 Proteoglycan synthesis in chondrocyte cultures from osteoarthrotic and normal human articular cartilage. Biochim Biophys Acta 717:190-201

9. Schmid TM, Conrad HE 1982 A unique low molecular weight collagen secreted by cultured chick embryo chondrocytes. J Biol Chem 257:12444-12450

10. Vittur F, Dumontier MF, Stagni N, Corvol M 1983 In vitro biosynthesis by articular chondrocytes of a specific low molecular size proteoglycan pool. FEBS Lett 153:187-193

11. Klagsbrun M, Langer R, Levenson R, Smith S, Lillehei C 1977 The stimulation of DNA synthesis and cell division in chondrocytes and 3T3 cells by a growth factor isolated from cartilage. Exp Cell Res 105:99-108

12. Corvol MT, Dumontier MF, Rappaport R, Guyda H, Posner BI 1978 The effect of a slightly acidic somatomedin peptide (ILAs) on the sulphation of proteoglycans from articular and growth plate chondrocytes in culture. Acta Endocrinol 89:263-275

13. Corvol MT, Dumontier MF, Garabedian M, Rappaport R 1978 Vitamin C and Cartilage. II. Biological Activity of 25-hydroxycholecalciferol and 24,25and 1,25-Dihydroxycholecalciferols on cultured growth plate chondrocytes. Endocrinology 102:1269-1274

14. Webber RJ, Sokoloff L 1981 In vitro culture of rabbit growth plate chondrocytes. 1. Age-dependence of response to fibroblast growth factor and "chondrocyte growth factor." Growth 45:252-268

15. Carrascosa A, Sanz-Tsgris L, Corvol MT, Rappaport R 1981 Biological effect of estradiol on phosphatase activities in rabbit cultured chondrocytes. Pediatr Res 15:1542 (abstr)

16. Trechsel U, Dew G, Murphy G, Reynolds JJ 1982 Effects of products from macrophages, blood mononuclear cells and of retinol on collagenase secretion and collagen synthesis in chondrocyte culture. Biochim Biophys Acta 720:364-370

17. Mitrovic D, McCall E, Dray F 1982 The in vitro production of prostanoids by cultured bovine articular chondrocytes. Prostaglandins 23:17-28 
18. Guenther HL, Fuenther HE, Froesch ER, Fleisch H 1982 Effect of insulin-like growth factor on collagen and glycosaminoglycan synthesis by rabbit articular chondrocytes in culture. Experientia 38.979-981

19. Audi L, Carrascosa A, Ballabriga A 1984 Androgen metabolism by human fetal epiphyseal cartilage and its chondrocytes in primary culture. $\mathbf{J}$ Clin Endocrinol Metab 58:819-825

20. Corvol MT, Dumontier MF, Rappaport R 1975 Culture of chondrocytes from the proliferative zone of epiphyseal growth plate cartilage from prepubertal rabbits. Biomedicine 23:103-107
21. Burton K 1956 A study of the conditions and mechanism of the diphenylamine reaction for the colorimetric estimation of DNA. Biochem $\mathrm{J}$ 62:315-323

22. Wiebkin OW, Muir H 1977 Synthesis of cartilage-specific proteoglycan by suspension cultures of adult chondrocytes. Biochem J 164:269-272

23. Yasumoto S, Kato Y, Oguri K, Yamagata S, Yamagata T 1980 Maintenance of phenotypic properties by chondrocytes cultured in suspension. Dev Growth Differ 22:445-459

24. Franzén A, Fjörnsson S, Heinegard D 1981 Cartilage proteoglycan aggregate formation. Biochem J 197:669-674

\title{
The Effect of Short-Term Starvation on Mucosal Barrier Function in the Newborn Rabbit*
}

\author{
DEBORAH ROTHMAN, JOHN N. UDALL, KAM Y. PANG, SARA E. KIRKHAM, AND \\ W. ALLAN WALKER \\ Combined Program in Pediatric Gastroenterology and Nutrition, Massachusetts General Hospital and Children's \\ Hospital, Department of Pediatrics, Harvard Medical School, Boston, Massachusetts 02114
}

\begin{abstract}
The compromised human newborn frequently presents with overwhelming feeding problems which lead to inadequate intake. These problems may affect the development of the small intestine, especially mucosal barrier function, leading to increased infections and susceptibility to allergens. To study this, an animal model was established using neonatal rabbits deprived of nutrients from birth until $\mathbf{7 2} \mathrm{h}$. Mucosal barrier function was compared in deprived and control (naturally fed 72-hold animals) rabbits by measuring immunoreactive bovine serum albumin in serum $4 \mathrm{~h}$ after intragastric infusion of crystalline bovine serum albumin $(200 \mathrm{mg} / 100 \mathrm{~g}$ body weight). Trypsin activity was measured in rinse fluid obtained from the small intestine. Representative sections of jejunum from control and experimental animals were formalin fixed and stained with hematoxylin and eosin for morphologic comparison. Following the bovine serum albumin feeding, a significantly increased serum immunoreactive bovine serum albumin and significantly decreased trypsin-like activity of the small intestinal rinse fluid was noted in starved animals compared to controls. In addition, the enterocytes of malnourished animals were more cuboidal and contained fewer and smaller supranuclear granules on microscopic examination than the enterocytes of controls. This study suggests that short-term starvation in newborns affects mucosal barrier function. Acute starvation may place newborns at increased risk for infections and allergic disease. (Pediatr Res 19: 727-731, 1985)
\end{abstract}

Received October 9,1984; accepted March 5, 1985.

Address correspondence to W. Allan Walker, M.D., Chief, Combined Program in Pediatric Gastroenterology and Nutrition, Massachusetts General Hospital, Boston, MA 02114

* Presented in part at the national meeting of the Society for Pediatric Research in Washington, D.C., 1983.

Supported by Grants AM-33506, GM-21700 from the National Institutes of Health. D.R. was a trainee with the Training Grant for Research and Trauma (5T32 GM-07035).
Abbreviations

BSA, bovine serum albumin i-BSA, immunoreactive BSA PBS, phosphate-buffered saline

The compromised human newborn frequently presents with overwhelming feeding problems and grossly inadequate intakes are common. The extent to which this affects the differentiation and development of the small intestine, especially in terms of barrier function, has not been studied. The intestine plays a major role in preventing a variety of intraluminal substances, such as food antigens, microorganisms, and toxins, from penetrating the mucosal barrier and entering the systemic circulation.

There is evidence that under conditions of chronic malnutrition intestinal barrier function is altered in older animals. This observation is based on the finding of increased uptake of both intact and large fragments of protein from the intestinal lumen into the circulation, suggesting that the gut is more permeable under these conditions $(1,2)$.

There is also indirect evidence that a similar phenomenon may occur in malnourished children. Chandra (3) reported an increase in circulating food antibodies in children with severe malnutrition, suggesting that food antigens may cross the gut to induce a systemic antibody response. Similarly, the uptake of pathogens may be increased and this may contribute to the high incidence of gastrointestinal and systemic infections in malnourished children.

Mucosal barrier function in the animal and human studies cited above was compromised only after long periods of nutrient deprivation in the postweaning state. There is no information on how the newborn responds to a similar insult or what effect a short-term period of starvation, which occurs commonly in the clinical setting, would have in the period immediately after birth when the intestine undergoes many changes while adapting to extrauterine life. 